\title{
Leadership Ideas Shaped by Digital Insights in Higher Education
}

\author{
Yu.M. Gruzina ${ }^{a}$, M.V. Mel'nichuk ${ }^{\mathrm{b}}$, M.A. Belogash ${ }^{\mathrm{c}}$ \\ Financial University, Moscow, Russia \\ ${ }^{\text {a } h t t p s: / / o r c i d . o r g / 0000-0002-6656-1156 ; ~}{ }^{\text {b }}$ https://orcid.org/0000-0002-7720-7443; \\ c https://orcid.org/0000-0003-2275-9950
}

\begin{abstract}
The paper deals with the problem of exploiting the potential of digitalization at scale by organizations in the age of information technologies and advanced analytics of data. Being at the forefront of social progress, universities inspire managers, training staff and students to reset their working, thinking and leading initiatives and embrace digital transformation of the educational environment. The study aims to research the modern thought on transformational leadership befitting universities' distinguished title of growth engines. The methodological framework comprises modern sociological, psychological, management and complex systems science theories of leadership. The paper analyzes organizational leadership models, explains their weak and strong points, formulates the terms of realizing the leadership phenomenon in the context of digitalization, studies the Financial University under the Government of the Russian Federation's experience in introducing the elements of the 'digital university' model. The findings support the idea that generative leadership is attainable through inter-layer and inter-cluster interaction of all educational environment members. The paper suggests a mechanism of transforming hierarchical models into generative leadership models. The theoretic and practical significance is the validation of interconditionality of digitalization and a leadership ecosystem as a variety of communications, complexity of interrelations and integrity of functioning of educational leaders.

Keywords: digitalization; inter-layer and inter-cluster interaction; generative leadership; digital university; leadership ecosystem
\end{abstract}

For citation: Gruzina Yu.M., Mel'nichuk M.V., Belogash M.A. Leadership ideas shaped by digital insights in higher education. Upravlencheskie nauki = Management sciences in Russia. 2019;9(4):75-84. (In Russ.). DOI: 10.26794/2404-022X-20199-4-75-84

ОРИГИНАЛЬНАЯ СТАТЬЯ

\section{Модели лидерства, удовлетворяющие цифровизации высшей школы}

\author{
Ю.М. Грузина ${ }^{a}$ М.В. Мельничук ${ }^{b}$, М.А. Белогаш ${ }^{c}$ \\ Финансовый университет, Москва, Россия \\ a https://orcid.org/0000-0002-6656-1156; ' https://orcid.org/0000-0002-7720-7443; \\ c https://orcid.org/0000-0003-2275-9950
}

\begin{abstract}
АННОТАЦИЯ
Поскольку знания становятся основным фактором экономического роста, а высшее образование выходит в авангард общественного прогресса, вузам необходимо в ближайшие годы трансформировать образовательную среду менеджмента и изменить деятельностные, мыслительные и лидерские модели профессорско-преподавательского состава и студентов вузов. В статье проанализированы современные теории трансформационного лидерства, отвечающего высоким требованиям университета как двигателя экономического роста. Методологическая база исследования включает социологические, психологические, управленческие теории лидерства, а также лидерство с позиций теории
\end{abstract}

(c) Gruzina Yu.M., Mel'nichuk M.V., Belogash M.A., 2019 
сложных систем. Проведен анализ особенностей моделей организационного лидерства, обоснованы их преимущества и недостатки, сформулированы условия реализации феномена лидерства в условиях цифровизации, изучен опыт по внедрению элементов модели «цифрового университета» Финансового университета. Авторы исследования полагают, что в рамках межуровнего и межкластерного взаимодействия всех участников образовательной среды модель порождающего лидерства реальна и достижима. Предложен механизм перехода от иерархических моделей к моделям порождающего лидерства. Теоретическая и практическая значимость исследования заключается в обосновании взаимообусловленности цифровизации и экосистемы лидерства как многообразия информационного обмена, многокомпонентности взаимодействия и целостности функционирования лидеров образования.

Ключевые слова: цифровизация; межуровневое и межкластерное взаимодействие; порождающее лидерство; цифровой университет; лидерская экосистема

Для цитирования: Грузина Ю.М., Мельничук М.В., Белогаш М.А. Модели лидерства, удовлетворяющие цифровизации высшей школы. Управленческие науки. 2019;9(4):75-84. DOI: 10.26794/2404-022X-2019-9-4-75-84

\section{Introduction}

Societies and their higher educational institutions have been developing in a cross-functional mode, the latter being the development basis for social and economic prosperity. For all the progress achieved for the last decade, Russian universities still have to unravel the global forces, which model the concepts of innovation in education, establish a balance between the preservation, generation and dissemination of knowledge to meet the social, economic and intellectual needs of society.

Having strong bonds with society, the $21^{\text {st }}$ century universities are under the pressure to become the engine of economic growth and social progress. Knowledge and professional competence have become the key factors of a nation's economic benefits, liberalization and innovation. In the context of the fast developing environment, universities gather innovative capacity, which enables them to establish the new standards of social, economic and cultural development [1].

\section{Statement of the problem and key research questions}

Universities have obviously contributed to the social advancement. Sustainable social and economic growth depends on the nation's level of education because it is education that fosters the economy's most valuable intellectual wealth. Thus, there is a growing demand for universities, which provide for top learning outcomes, faculty development and demand-driven and practice-oriented research capacity. Higher educational leaders agree that universities play a pivotal role in the age of transformations since all other sources of prosperity and social mobility have been overridden by knowledge [2].
In order to spearhead social, economic and intellectual progress, higher education should shape by and draw their agenda from the areas of focus of society because it is the organizational capacity that ensures its advancement [3]. Thus, the challenge for universities is the need for transformation. Despite the major changes brought about in higher education during the past three decades [4] there is a pressure for universities to reach a compromise between innovative transformation and maintaining their status-quo, i.e. providing a product, which meets current social, economic and intellectual needs, and adding the value to the society's knowledge capital [5]. It can be derived that universities' transformation in the climate of social and economic change makes them the driver of society's transformation since they are able to set the pace and direction of evolution of society and transform coefficiently with it [1].

How much are universities committed to transformation? Who will be transformational leaders in higher education? Whose potential will be instrumental in the achievement of the university's high mission? What are the development trends for Russian universities - to be teaching-oriented or research-oriented? Should Russian universities be driven by current economic needs in skilled labor? Should academic staff rely on knowledge transmission or knowledge generation? Should the university staff strain for pure science or collectively seek for its practical implication [6]? How should universities avoid extremities and find a reasonable compromise?

On one hand, higher educational institutions strive for preserving their teaching legacy they take special proud in. On the other hand, they aim to be ahead of the times. What are the prerequisites of tipping the balance in favor of transformation? 
What forces are able to realize innovative strategies and undertake a study necessary to find access to a benchmark of progress?

These problems have long been on universities' agenda. Their novel nature comes from the urgent imperative of their resolution. Digitalization permeates all areas of life. Neither are universities immune to advancement. Universities transform not only their basic teaching routines but also their intercommunication patterns within their learning environments. Digitalization has become sine qua non of transformation. However, digital change of education is at the early stage. Thus, digitalization of universities is a sine qua non condition of maintaining their leadership position in society.

Being the art of motivating people to achieve the goals to be sought, leadership has been the object of multidisciplinary studies. Higher educational leadership can best determined from sociological, pedagogical, managerial perspectives as well as in the context of complexity theory.

\section{Current thinking about leadership models}

John. P. Kotter, one of the foremost authorities on organizational change and leadership, criticized modern management techniques and deprecated the hierarchical structures and organizational processes used in universities for decade-long periods. What most interests us is Kotter's inference that traditional management techniques are no long efficient because they fail to keep up with the fast pace of the modern world and benchmark performance against competitors [7]. Giving credit to the effectiveness of hierarchical structures and management techniques in dealing with daily routines, John P. Kotter (2012) suggests that organizations combine traditional hierarchies with complex networking architectures able to respond to any change in quality, which enables the organization to make timely decisions in the face of emerging challenges. The utility of a double operational system depends not on the management functions but on the efforts of change agents who fully realize the necessity of transformation. Having ensured the continuity of operational data collection and the interaction of the two systems, organizations develop a unique adaptable and transformable operational network. The concept of "double operational system" realized in the educational environment of universities will help mitigate any negative effects of 'managerialism', promote democratic values and provide for universities' transfer from operating stiff linear administrative command systems to responsively interacting with change agents.

Organizational transformations do not in every instance meet the interests of frontline employees who bring transformation into effect [8]. Transformation for the good of transformation in the absence of real demand on the part of all organizational members is doomed to failure foreasmuch as an external digital shell of the organization filled with traditional hierarchical structures, chains of command and passive subordinates is unable to ensure expected outcomes. Multiparadigm approach to the transformation of different subsystems of relationships of homogeneous elements of the organization could be an efficient alternative to linear organizational transformations [9].

Among the scholars, supporting organizational transformation there is an opinion that it is the receivers of change or employees and not executives that could be most effective. Transformational processes managed from top downward and from the bottom upwards are not conflicting but optimizing [10]. The analysis of reasons why employees support or sabotage transformational initiatives of the executive staff Armenakis et al. conclude that it is more rewarding to cultivate employees' openness to change through their engagement in transformation rather than overcome their resistance. Drawing on the above concept, we conclude that transformational initiatives in the Russian universities should be mapped out along the multidimensional lines of the organizational structure, the participation of change receivers being an indispensable precondition of successful transformation.

The concept of knowledge-based economic growth features the ever-increasing role of information technologies and education in the achievement of the ultimate economic efficiency based on digital transformation. Advanced production technologies, neurotechnologies, the Internet of things and artificial intelligence cannot be imbedded into social and economic development of society without training digital experts who will be the digital leaders of the organization and speed up on transformational processes, shape its mindsets for effective digital communication, and condition the dynamics of restating normality [11-13]. 
According to the national project of the Russian Federation on "Digital Economy", digitalization is based on efficiently functioning sectorial digital platforms of the basic business domains. In the wake of this transformation, all public universities will have introduced the elements of the 'Digital University' model by the end of 2023. The model proposed is a complex of methodological approaches, digital techniques, digital resources, services and infrastructure proving for teaching and research activities as well as management procedures to meet the requirements of a digital economy. One of the key measures of realization of the national project is the training support of the highly qualified personnel for the digital economy.

The realization of the national project will bring about fundamental changes as a result of information traffic available to all members of the educational process. The emergent ecosystems will be catalysts of developing new methods dramatically different from traditional methods and training practices. Such transformation will consequentially stop the divide between the management, academic staff and students from being established in the matter-of-course hierarchical manner. In the ecosystem context, the information flow, educational resources, informative and consulting teaching services, competences, faculty expertise, students' deeply engrained specialist knowledge and high motivation for research will coalesce or outgrow their disintegration and will accessible for each proactive member of the education environment. The success of an educational digital ecosystem depends on those who manifest leadership skills in the use digital resources and all the educational facilities it brings about for universities.

Hence, Russian universities should more than ever before give a new meaning to the concept of educational leadership, as it is the most effective driving force of transformation. It is especially vital for universities to bring up experienced and viable leaders able to accomplish the mission of society transformation. No innovation occurs in its own right and any change requires a leader [13, 14].

Our research has identified certain theories of higher educational leadership. According to the findings, society is concerned with the problem of whose leadership efforts will benefit universities in the long run. The reason for this concern is the fact that universities possess great an educative force and ability to grow new leaders who will transform society and affect the concept of leadership due to the globalization economic processes, internationalization of science and growth of international academic mobility [15].

The review of the main leadership philosophies dominating the worldwide thinking for the period of the last 100 years has revealed a wide range of leadership models - from command and control to individualistic and to collective, participatory and transformational models. Depending on the scope and intensity of research, subject areas, comprehensiveness and concentration, universities face the problems whose solution requires an integral use of different leadership models. Particularly but not exceptionally, the most efficient is the combination of the authoritarian or top-down leadership model instituted by the management hierarchies and focused on educating students teaching staff or downto-top leadership [15]. Hence, university executives should distribute or delegate statutory leadership powers, which are typically the prerogative of the administrative staff, as the command and control approach is no longer relevant to transformational processes [16] and even harmful for the management of the academic community [15].

Being apprehensive of the educational management's focus on grading universities based on key performance indicators (academic citation, students' academic progress, employers' appraisal), the analysts of the higher educational leadership phenomenon state that the most urgent requirement of the day is the stimulation of leadership initiatives among the academic personnel having non - executive positions. Moreover, the leadership quality should manifest itself not only in higher values of KPI but also in the cultivation of personalities holding on the same views and ready to become followers both in teaching and research activities of the university. Consequently, the delegation of leadership roles and responsibilities in order to redistribute and re - channel leadership efforts will refocus leadership powers from the heroic or central organizational leader to other members of the educational environment, thus amalgamating hierarchical, interlayer and interdisciplinary development and collaboration trends [17]. The performance of a traditional linear organization will be improved due to the leadership contribution of effect-oriented experts in embedding transformation, i.e. through 
the directing, controlling and motivating efforts of the teaching personnel in class as well as at the departmental levels of the university. Such leadership models transform organizational culture owing to the collaboration of formal and informal leaders, teachers, executives, and experts from among the top, middle and low-level personnel [17].

Richard Bolden made a particular contribution to the leadership theory in higher education. Having determined the main trends as the functioning of "hybrid configurations" of management, he suggests representative, collective, distributed and emergent leadership models. Hybrid configurations encompass both delegated leadership powers (formal top-down management chains of command) and emergent influence (informal leadership down-to-top initiatives) [18]. Of major interest for our research is the authors' conclusion that both individual hierarchical management and general bottom-up management approaches to the delegation of leadership powers at all levels of the organization are worth consideration and application in modern higher education $[18,19]$.

As for the middle management level leadership models, it should be mentioned that meeting the orders of senior management and the expectations of subordinates requires rigid frameworks for the display of leadership efforts. The quality of middle level executives' leadership initiatives is determined by their professional interaction with university authorities, members of scientific schools and students. Of major difficulty is the achievement of a balanced distribution of leadership efforts between teaching quality assurance and research and procedure development excellence, while negotiating communication barriers typical for hierarchical structures [20]. Middle level executives have to prioritize the problems of day-to-day operations, maintain professional workmanship, balance academic efforts, contain absolute parity on all the issues and operate in ever changing educational environment. Therefore, collective interaction and teamwork are the main leadership models in higher education [20].

Taking a micropolitical approach to leadership in higher education it should be said that there is a phenomenon of leadership behavior exerting influence on the members of the educational process, the result of which is the emergence of an informal culture able to transform the university's performance in the process of daily social, scientific, instructional and interpersonal interaction. The na- ture of micropolitical leadership helps to bridge the gap between the management theory, institutional and actual academic life of universities. Taking into account the fact that academic environments feature 'self-leadership', contradictory relationships and pressure groups pursuing their particular interests bring up individual rather corporate leaders [21]. Therefore, there is a need to effectively exploit the leadership potential of self - leaders through suppressing their disunity and providing for their collaboration in the leadership ecosystem context by means of information traffic and digital infrastructure to be used in providing informative and consulting educational services and research activities.

Within the framework of our research, of major interest is the concept of 'leaderism' [22] as an addition to the leadership model of 'managerism' in higher education. Leaderism means the ability of particular leaders to introduce a new transformational agenda, solve problems, attain the parity of interests, manifest inspiring enthusiasm and achieve the acceptance of organizational values. Having identified the sources of transformational leadership and having combined leaderism and managerism into a single model of the transforming leadership culture, higher educational management will develop a leadership model, which is specific for its leaders' high professionalism and the optimum quantity of bureaucratic barriers [23].

Having reviewed leadership models in the management, psychological, pedagogical and sociological aspects, we move on to considering the leadership phenomenon from the perspective of complexity science. The concepts of this theory open up opportunities for progress and innovation in higher education because they view leadership as a process evolving in terms of interlayer and inter-cluster crosswise interaction and affecting all members of cross-organizational communication. The authors of this leadership concept posit that crosswise interaction developing throughout the lifecycle of the organization in all its constituent parts encourages its improvement, which spawns innovation or a new capacity. Thus, the interaction of all members of the educational process is a true catalyst of transformation [3]. The authors suggest the term of 'generative of emergent leadership'. The selection of the term is not without reason as it means that transformation derives from the cumulative property 
Students' median estimates of scientific training departments of the Financial University, including inter alia estimates of each assessment criterion

\begin{tabular}{|c|c|c|c|c|c|c|c|c|c|}
\hline \multicolumn{10}{|c|}{ As of spring, 2019 / to be estimated out of a 10 possible points } \\
\hline Department & $\begin{array}{c}\text { Median } \\
\text { estimate }\end{array}$ & $\begin{array}{l}\text { Able to } \\
\text { clearly, } \\
\text { intelligibly } \\
\text { and } \\
\text { consistently } \\
\text { deliver the } \\
\text { material in } \\
\text { accessible } \\
\text { language }\end{array}$ & $\begin{array}{l}\text { Provides } \\
\text { cohesion of } \\
\text { theoretical } \\
\text { knowledge } \\
\text { and } \\
\text { practice- } \\
\text { oriented } \\
\text { components } \\
\text { of future } \\
\text { profession }\end{array}$ & $\begin{array}{l}\text { Able to } \\
\text { spark the } \\
\text { interest } \\
\text { and } \\
\text { engage } \\
\text { students } \\
\text { in the } \\
\text { training } \\
\text { process }\end{array}$ & $\begin{array}{c}\text { Puts forward } \\
\text { clear } \\
\text { assessment } \\
\text { requirements }\end{array}$ & $\begin{array}{l}\text { Unbiased in } \\
\text { assessing } \\
\text { students' } \\
\text { performance }\end{array}$ & $\begin{array}{l}\text { Interested } \\
\text { in } \\
\text { improving } \\
\text { the quality } \\
\text { level of } \\
\text { learning } \\
\text { outcomes }\end{array}$ & $\begin{array}{c}\text { Benevolent } \\
\text { and tactful } \\
\text { with } \\
\text { students }\end{array}$ & $\begin{array}{c}\text { Accessible for } \\
\text { extra-curricular } \\
\text { communication } \\
\text { on training and } \\
\text { research issues } \\
\text { in counseling } \\
\text { classes and } \\
\text { remotely }\end{array}$ \\
\hline $\begin{array}{l}\text { University's } \\
\text { median } \\
\text { estimate }\end{array}$ & 8.50 & 8.51 & 8.48 & 8.21 & 8.43 & 8.49 & 8.49 & 8.78 & 8.57 \\
\hline
\end{tabular}

Source: developed by the authors.

of interaction. Innovative transformation can only be achieved as a result of successive interactions taking place throughout the organization and not due to the efforts of a single person. Emphasizing the superiority of the generative leadership model over the other models, the authors state that it is the only model interactive relationship which provides for new opportunities and unlocks the potential of organizational growth, which in turn promotes successful innovation, flexibility, and adaptability to dynamic environments. Moreover, innovation synonymizes with the emergence of not-yet-existing structures, models, connections or properties of the elements in a complex system.

Developing the concepts of the complexity science in terms of transformational leadership philosophy, Benjamin Lichtenstein and his colleagues transfer the focus of their research interest form top and middle level management towards the lower structural levels and new properties of the organization, which propel it to a higher level of development. Having applied the Complex Systems Leadership Theory in practice [24], convincingly assert that leadership emerges in a complex system when interactions make the system members form 'leader/follower' pairs within the system.

Thus, the scientific approach to leadership as an emergent property of complex systems evolving as a cumulative property of numerous inter-cluster interactions is of today the foremost and pertinent to the goals set for higher education by society in the age of digitalization of all focus areas. It is from the perspective of emergent leadership that it turns to be possible to determine the transformational leadership potential of such a complex system as a university.

\section{Aims and methods of research}

The aim of this research is the analysis of the transformational leadership model in higher education in the age of digital transformation and exploration for the source of leadership initiatives. The present study is focused on the activity of the Federal State Budgetary Educational Institution of Higher Education - the Financial University under the Government of the Russian Federation - an establishment with a 100-year history of university programs in different financial areas and Russia's best graduates with different financial qualifications. According to QS assessment, this university is among the top Russian universities ${ }^{1}$. The study relies on the official statistics provided by the analytics department of the Financial University.

The digital transformation of the Financial University remodels its training and education activities and stimulates leadership efforts of all members of the educational environment. Minds, civic positions, and professional targets become transformed by a process of interaction of students, teaching staff and management through the use of digital resources providing for regular information sharing. Put that

${ }^{1}$ QS Stars: Methodology. What criteria does QS Stars use when rating universities, and why? QS TOPUNIVERSITIES. URL: https://www.topuniversities.com/qs-stars/qs-starsmethodology (accessed on 06.08.2017). 
in context, the analysis of the academic performance based on digital resources provides subject selection guidelines, suggests research projects, scientific discussion platforms for and students as well as quality monitoring of educational programs. The cloud-based neuronet of the Financial University provides an on-line analysis of students' involvement in the processes of the educational environment. The survey of students' assessment of the quality of training "Students' Impression of Teachers" ensures feedback, encourages students' participation in managing the university, improves the quality of educational services and research, enhances the flow of managerial information, and motivates the teaching staff. The survey findings are considered by the departments and divisions at all management levels, in small professional groups and in all processes of intercomponent communications as they render possible to analyze the functional, professional, ethical, psychological and individual characteristics of the teaching staff as well as determine students' priorities and preferences in learning.

\section{Analysis and results}

Digital resources of the Financial University provide the feedback data about the quality of the training process the analysis of which enables the management to identify the potential of transformational changes in the interactive educational environment. In addition to its organizational and qualitativeeducational characteristics of its activities, among the transformational priorities of the Financial University are the research on Big Data analytical instruments, process social-economic models, blockchain economy models and crypto currency markets. Leadership initiatives of the Financial University in terms of digital transformations find expression in the initiative of the management, training staff and students to hold Russia's first thematic forum “Digital Mindset for Leaders" collaboratively with Michael Ruckman, Senteo Inc. Founder, President and CEO, a renowned extra-national expert in business transformation.

Thus, the developing digital environment of the university ensures the multi-subjectivity of assessment of the university's training activity, making timely educated management decisions, collaboration, collegiality and interaction in training and research.
The literature review provides theoretical justification of our study while the analysis of digital transformation, which ensures the interaction of all members of the educational environment, provides empirical evidence of the efficiency of the emergent leadership concept. The review of scientific concepts and leadership models suggests that transformation is the only development path for higher educational institutions, which seek flexible and adaptable transfiguration methods in order to maintain high educational standards and research deliverables.

Another logical inference is that higher education leadership models are on the track to transform from traditional hierarchical paradigms to a new leadership model, which combines administrative and individual leadership top-down, and down-to-top initiatives. The national project of the economy's digitalization presupposes the "Digital University" model implementation, the model being a complex of methodological approaches, digital technologies, digital resources and infrastructure, which ensure the conformity of educational, research and management activities with the requirements of the digital economy. The digital university model provides for the interlayer and inter-cluster communication of all members of the educational environment, responsiveness and adaptability of the university to dynamic processes in society and unlocks the potential of organizational development. Numerous interactions of the members of the educational environment ensured by the University's digital infrastructure are the display of their leadership efforts, which will generate organizational transformation processes, all of which implies that there is a possibility of transition from a linear leadership paradigm to a leadership ecosystem.

The university's digital ecosystem is to generate the leadership ecosystem and the formation of the latter is a guarantee of successful functioning of a digital university. The use of the term 'ecosystem' was originally connected with the biological life and subsequently used in the context of information technologies. In terms of organizational leadership models this term conveys analogy to multiple processes taking place in natural, digital and social environments [25] Such properties of natural and digital ecosystems as variety of shapes, complexity of interrelations, integrity of functioning, interaction and interdependence, adaptability, self-regulation 
and emergent properties find analogues in the properties of emergent leadership models ensured by the organizational digital infrastructure of the university. Having received the digital mechanisms and network channels of information-bearing signals which provide for the interaction of leadership efforts, the leadership ecosystem will burgeon out.

\section{Conclusion}

In the face of dynamic content development of society, universities' top executives, educators and instructional designers formulate the functional goals of university education in compliance with the requirements of social progress, set the targets and direct the colleagues' activity within the framework of the educational environment. In these circumstances, implicit leadership and all-member interaction guarantee the attainment of high performance. Self-identification and interaction in the course of mainstreaming leadership efforts form the basis for the emergence of co-thinkers' alliances and collegiate relationships in the segments of the educational process lacking a dialogue mode while the members of the educational process concurrently settle into leading and cohort roles. The transition from a multilevel hierarchical paradigm through omnichannel interactions towards a self-regulating, self-optimizing and spontaneously developing leadership ecosystem as an academic, informative-educational and exploratory knowledge-based environment for all-member interaction will facilitate decision-making and encourage innovative transformation due to the evolution of collaboration.

Thus, backed by the integrated leadership efforts of the relatively autonomous academic staff, the task complex of higher educational leaders is exponentially growing owing to the need to create an artfully balanced development strategy in terms of universities' strategic mission of thorough-going society's advancement in the aims of its intellectual, social and economic and cultural development. This should provide for discovering new horizons for university education attainable in a climate of collaboration, collective leadership and intercomponent communication.

\section{ACKNOWLEDGEMENT}

The paper is based on the results of the budgetary funded research carried out by the Financial University within the state assignment.

\section{БЛАГОДАРНОСТЬ}

Данная работа основана на результатах исследования, финансированного из средств бюджета, выполненного Финансовым университетом в рамках государственного задания.

\section{REFERENCES / СПИСОК ИСТОЧНИКОВ}

1. Vuori J. Distributed leadership in the construction of a new higher education campus and community. Educational Management Administration \& Leadership. 2019;47(2):224-240. DOI: $10.1177 / 1741143217725322$

2. Raagmaa G., Keerberg A. Regional higher education institutions in regional leadership and development. Regional Studies. 2017;51(2):260-272. DOI: 10.1080/00343404.2016.1215600

3. Rottmann C., Reeve D.W., Sacks R., Klassen M. An intersubjective analysis of engineering leadership across organizational locations: Implications for higher education. Canadian Journal of Higher Education. 2016;46(4):146173. URL: http://journals.sfu.ca/cjhe/index.php/cjhe/article/view/186198/pdf (accessed on 06.08.2017).

4. Jones S., Harvey M. A distributed leadership change process model for higher education. Journal of Higher Education Policy and Management. 2017;39(2):126-139. DOI: 10.1080/1360080X.2017.1276661

5. Makina A. The theory of connectivism in enhancing leadership/management competences in e-learning in higher education. African Educational Research Journal. 2016;4(4):152-159. URL: http://www. netjournals.org/pdf/AERJ/2016/4/16-038.pdf (accessed on 06.08.2017).

6. Stensaker B., Bilbow G. T., Breslow L., Vaart R., eds. Strengthening teaching and learning in research universities. London: Palgrave Macmillan; 2017. 228 p.

7. Kotter J. P. Accelerate! Harvard Business Review. 2012;(11):45-58. URL: https://hbr.org/2012/11/ accelerate 
8. Klein C., Lester J., Rangwala H., Johri A. Learning analytics tools in higher education: Adoption at the intersection of institutional commitment and individual action. Review of Higher Education. 2019;42(2):565-593. DOI: 10.1353/rhe.2019.0007

9. Graetz F., Smith A.C.T. Managing organizational change: A philosophies of change approach. Journal of Change Management. 2010;10(2):135-154. DOI: 10.1080/14697011003795602

10. Heyler S. G., Armenakis A. A., Walker A. G., Collier D. Y. A qualitative study investigating the ethical decision making process: A proposed model. The Leadership Quarterly. 2016;27(5):788-801. DOI: 10.1016/j.leaqua.2016.05.003

11. Péladeau P., Herzog M., Acker O. The new class of digital leaders. Tech \& Innovation. 2017;(88). URL: https://www.strategy-business.com/article/The-New-Class-of-Digital-Leaders?gko=a250f (accessed on 14.09.2019).

12. Fedorova I. Yu., Elistratova E. Yu. Improving the mechanism of educational system funding. Nauchnoissledovatel'skii finansovyi institut. Finansovyi zhurnal = Financial Research Institute. Financial Journal . 2012;(1):149-158. (In Russ.).

Федорова И.Ю., Елистратова Е.Ю. Совершенствование механизма финансирования системы образования. Научно-исследовательский финансовый институт. Финансовый журнал. 2012;(1):149-158.

13. Sakharova N.V. Estimation of creative potential implementation in the research activity of a higher education establishment. Nauchno-issledovatel'skii finansovyi institut. Finansovyi zhurnal = Financial Research Institute. Financial Journal. 2013;(1):159-164. (In Russ.).

Сахарова Н.В. Оценка реализации творческого потенциала в научно-исследовательской деятельности вуза. Научно-исследовательский финансовый институт. Финансовый журнал. 2013;(1):159-164.

14. Dugan J.P., Humbles A.D. A paradigm shift in leadership education: Integrating critical perspectives into leadership development. New Directions for Student Leadership. 2018;(159):9-26. DOI: 10.1002/ yd.20294

15. Black S. A. Qualities of effective leadership in higher education. Open Journal of Leadership. 2015;(4):4366. DOI: $10.4236 / 0 j 1.2015 .42006$

16. Goffee R., Jones G. Leading clever people. Harvard Business Review. 2007;85(3). URL: https://hbr. org/2007/03/leading-clever-people (accessed on 09.12.2019).

17. Jones S., Harvey M., Hamilton J., Bevacqua J., Egea K., McKenzie J. Demonstrating the impact of a distributed leadership approach in higher education. Journal of Higher Education Policy and Management. 2017;39(2):197-211. DOI: 10.1080/1360080X.2017.1276567

18. Bolden R. Distributed leadership in organizations: A review of theory and research. International Journal of Management Reviews. 2011;13(3):251-269. DOI: 10.1111/j.1468-2370.2011.00306.x

19. Mitic R.R. Challenges to positive leadership in US higher education: Lessons from US political economy. Perspectives on Global Development and Technology. 2015;14(1-2). DOI: 10.1163/15691497-12341345

20. Branson C. M., Franken M., Penney D. Middle leadership in higher education: A relational analysis. Educational Management, Administration \& Leadership. 2015;44(1):128-145. DOI: $10.1177 / 1741143214558575$

21. Lumby J. In the wings and backstage: Exploring the micropolitics of leadership in higher education. London: Leadership Foundation for Higher Education. 2015. 36 p. URL: https://eprints.soton. ac.uk/386161/1/_soton.ac.uk_ude_PersonalFiles_Users_jlumby_mydocuments_Text\%2520Document\% 2520Feb.\%25202015_JL\%2527s\%2520articles_LF\%2520J\%2520Lumby\%2520In\%2520the\%2520Wings.pdf (accessed on 06.08.2017).

22. O'Reilly D., Reed M. 'Leaderism': An evolution of managerialism in UK public service reform. Public Administration. 2010;88(4):960-978. DOI: 10.1111/j.1467-9299.2010.01864.x

23. Crevani L., Ekman M., Lindgren M., Packendorff J. Leadership cultures and discursive hybridization: On the cultural production of leadership in higher education reforms. International Journal of Public Leadership. 2015;11(3-4):147-165. DOI: 10.1108/IJPL-08-2015-0019

24. Lichtenstein B.B., Uhl-Bien M., Marion R., Seers A., Orton J.D., Schreiber C. Complexity leadership theory: An interactive perspective on leading in complex adaptive systems. Emergence: Complexity \& 
Organization. 2006;8(4):2-12. URL: http://digitalcommons.unl.edu/cgi/viewcontent.cgi?article=1007 \& context=managementfacpub (accessed on 09.12.2019).

25. Schyns B., Kiefer T., Kerschreiter R., Tymon A. Teaching implicit leadership theories to develop leaders and leadership: How and why it can make a difference. Academy of Management Learning \& Education. 2011;10(3):397-408. DOI: 10.5465/amle.2010.0015

\section{ABOUT THE AUTHORS}

Yuliya M. Gruzina - Cand. Sci. (Econ.), Associate Professor, Associate Professor of Department of Management, Financial University, Moscow, Russia

YMGruzina@fa.ru

Marina V. Mel'nichuk - Dr. Sci. (Econ.), Professor, Professor of Department of Language Training, Financial University, Moscow, Russia

MVMelnichuk@fa.ru

Marina A. Belogash - Associate Professor, Professor of Department of Language Training, Financial University, Moscow, Russia

MBelogash@fa.ru

\section{ИНФОРМАЦИЯ ОБ АВТОРАХ}

Юлия Михайловна Грузина - кандидат экономических наук, доцент, доцент Департамента менеджмента, Финансовый университет, Москва, Россия

YMGruzina@fa.ru

Марина Владимировна Мельничук - доктор экономических наук, профессор, профессор Департамента языковой подготовки, Финансовый университет, Москва, Россия MVMelnichuk@fa.ru

Марина Анатольевна Белогаш - доцент Департамента языковой подготовки, Финансовый университет, Москва, Россия

MBelogash@fa.ru

The declared contribution of the authors:

Gruzina Yu.M. - formulation of research hypotheses.

Mel'nichuk M.V. - data collection for research; preparation of the paper text.

Belogash M.A. - preparation of literature review; preparation of the paper text.

\section{Заявленный вклад авторов:}

Грузина Ю.М. - формулировка гипотез исследования.

Мельничук М.В. - сбор данных для проведения исследования, подготовка текста статьи.

Белогаш М.А. - подготовка обзора литературы, подготовка текста статьи.

The paper was submitted on 30.10.2019; revised on 15.11.2019 and accepted for publication on 25.11.2019. The authors read and approved the final version of the manuscript.

Статья поступила в редакцию 30.10.2019; после рецензирования 15.11.2019; принята к публикации 25.11.2019.

Авторы прочитали и одобрили окончательный вариант рукописи. 